\title{
Mass Media as Means of Initiating Community Developmental Programmes in Akoko North West Local Government Area, Ondo State, Nigeria
}

DOI: https://doi.org/10.47175/rielsj.v1i2.85

\author{
${ }^{1}$ Department of Pure and \\ Applied Sciences, Rufus Giwa \\ Polytechnic, Owo, Ondo State, \\ Nigeria \\ ${ }^{2}$ Department of Adult \\ Education, Faculty of \\ Education, Adekunle Ajasin \\ University, Akungba-Akoko, \\ Ondo State, Nigeria
}

| Gani A. Ogundahunsi ${ }^{1, *} \mid$ Francis O. Olaniyi ${ }^{2}$ |

22drfrancisolaniyi@gmail.com

\begin{abstract}
The study examined the mass media as means of initiating community developmental programmes in Akoko North West Local Government Area of Ondo State, Nigeria. The study adopted descriptive research design of the survey type. The sample for the study consisted of 120 respondents in Akoko North West Local Government Area of Ondo State, Nigeria. The study raised four research questions which the data were collected through questionnaire and also tested and analyzed with descriptive statistics. The findings showed that the mass media was the best platform for mobilizing people of the community for participation and also attracts government attention to communities for developmental programmes. Based on the findings of the study, it is recommended that residents' collaboration and empowerment form of participation is encouraged by NGOs and development agencies.
\end{abstract}

KEYWORDS

Mass media; community; developmental programmes

\section{INTRODUCTION}

The media, right from the independence of the nation have always been agents of development. They are used to engender social, cultural and political development in a society. Governments and their agencies have used the mass media including broadcast media to mobilize the masses for development. The media are used to convey developmental policies and actions to the people and the masses in-turn use the media to convey their developmental needs as well as feedback to the government. Communication and development has been viewed as closely intertwined phenomena, where one is believed to guarantee the other (Servaes, 2008).

Mass media can be a vital component of initiatives that involve voluntary behaviour and change thus communication becomes important in playing advocacy role by listening, gathering data and informing. Again, communication can be used to persuade and train people through social mobilization and to help change behaviours by educating and managing change where people have options to change their ways of life (Servaes, 2008). The media in today's world has been described as a combination of content, comprising a scientific and artistic ensemble of music, film, TV, radio video, publications, advertisement, and electronic games (Locksley, 2009).

Communication is central to this task in many ways; thus, it enables planners, when identifying and formulating development programmes, to consult with people (the stakeholders) in order to take into account their needs, attitudes and traditional knowledge (Balogun, 2014). The traditional role of the media to facilitate the exchange of information, educate and enlighten the citizens has long been identified as very crucial. The media also function to keep the citizens abreast of developments, expose them 
to new ideas, and serve as a veritable platform for them to contribute to the quality of government's policy, and to the good governance of the nation. Purpose of development is improvement in the quality of lives of the people - their social and material wellbeing. It also means continued improvement in the human and economic well-being of the people from one stage to another (Chambers, 1991).

\section{The Objective of the Study}

The objective of the research is to investigate mass media as a means of initiating community developmental programmes in Akoko North West Local Government Area, Ondo State, Nigeria. This knowledge and understanding can assist in several life-changing developmental programmes. The specific objectives of the study are to:

1. examinehow mass media contributes to community developmental programmes.

2. examine the factors which influence the role of media in Akoko North West Local Government Area community developmental programmes.

3. investigate ways in which the mass media initiates development in the society.

4. find out how communication helps to promote developmental projects and bring about positive changes to the lives of people in Akoko North West Local Government Area of Ondo State, Nigeria.

\section{Research Questions}

The following research questions were raised to guide the study:

1 How mass media does contributes to community developmental programmes?

2 What are the factors which influence the role of mass media in developmental programmes in Akoko North West Local Government Area of Ondo State, Nigeria?

3 In what ways does the mass media initiates and enhance developmental programmes in the society?

4 How does communication helps to promote developmental projects that bring about positive changes to the lives of the people in Akoko North West Local Government Area of Ondo State, Nigeria?

\section{LITERATURE REVIEW}

\section{Concept of Development}

Development is a word with an ever-changing definition. It has no shape, no parameter, and has a connotation of which assumes the most convenient definition for the context in which it is applied. Yet despite numerous semantic debates found within the development literature, it is important to recognize that such discourse is not an end in itself, but merely a launching point for important, meaningful methodological discourse and design (Midgley, 2006).

Development is best described as a "philosophy, a process, the outcome or product of that process, and a plan guiding the process towards desired objectives" (Sharpley, 2002). As a philosophical concept, it describes a desirable future state to which a society might progress, and will highly influence the formation of development policies.

\section{Concept of Mass Media}

Media is the plural form of medium (a means or agency, instrument through which communication or contact is made). According to Kirby et al (1997), medium refers to a single source of information or technique of passing information while media refers to more than one source of information designated to reach out to many people- (a mass 
Audience). Nwoke (1997) viewed media, as channels through which message, information, ideas and knowledge are conveyed to people or inculcated into learners. In a related note, Giddens (2004) defined media as a wide variety of forms, including; television, newspapers, films, magazines, advertisements, video games, CDs, satellite cables and web or internet facilities that reach mass audience. In a common parlance, media can be define as the various means of mass communication, including television, radio, film, magazines and newspapers, together with the people involved in their production (Anakwe, A. , Majee, W. , \& Keller, K.J.M. , 2018).

Media according to Akanmu and Akinsanya (2004) is the channels through which messages, information, ideas and knowledge are conveyed and or disseminated. They are the tools or instruments through which stimulus can be passed out or obtained. They further stressed that when media are used for educational purposes, they are regarded as educational media.

The most comprehensive definition of the term media today was that given by the Commission of Definition and Terminology. To that body, educational media are those which are manipulated, seen, heard and talked about plus the instruments, which facilitate such activities (Akanmu and Akinsanya, 2004). There are inexhaustible list of media that are used and can be used in education for the purpose of enhancing the effectiveness of instruction. There are again, many ways of categorizing the different types of educational media both projected and non-projected aids. Akingbulu (2011) classified them, first into locally produced and commercially produced Media materials.

\section{Types of Media}

It is now very appropriate to classify and discuss how the varied media can be manipulated through varied technological and electronic process towards engineering and developing the society.

Electronic Media: The electronic media can be subdivided in to radio, being an audiomedium only; a broadcast medium using only the aural medium of information dissemination, with rather in exhausive reach and peroration; with relatively simpler methods of broadcasts to reach far and wide; appealing to both the blind and the rightful patrons. On the other hand, the television is the audio-visual broadcast medium, perceptibly tactile, pictorial and photographic in its visual delineations, further enrich with all the magic sound and vision, through which the medium can create its own appeal and impression.

Print Media: The print media, consisting of newspapers, magazines, hard or soft, do not belong to broadcast media, through mass -circulated, with very many people targeted reading the same papers, massages or articles simultaneously, but individually and isolated. Their massages may be understood, misunderstood, interpreted and misinterpreted variably, creating like appeals and impressions among the citizens for good or bad; enhancing or hindering development.

Celluloid Media: These consist of what can be called cinemas or films, also called motion pictures collectively, described as a sequence of pictures of objects photographed in motion by specifically designed cameras (called motion picture camera) and thrown on a screen by a projector (motion picture), in such rapid successions as to give illusion of natural movements. Live programmes can be presented in this form through the instrumentality of celluloid. When properly manipulated as such, the celluloid media can also educate, inform and entertain. They may be manipulated to create targeted effect or results desired. 


\section{Media and Community Development}

According to (Cheng, Y., Jin, Y., Hung-Baesecke, C.-J. F., \& Chen, Y. R., 2019) mass media can be distinguished from other forms of human communication by its characteristics and functions. The phrase mass media evokes images on TV, radio, motion pictures, newspaper, comic, books and magazines. It is not only the technical component of this modern communication system that distinguished them as mass media but rather their distinctive operating condition primary among which are, the nature of the audience, the communication experience, and the communicator. The nature of the audience of mass communication is directed towards a relatively large, heterogeneous, and anonymous audience. The greatest challenge and concern of the seventeenth century contemporaries was the ideal of breeding informed society (Napoli, 2008). These trends in human development had always enjoyed the essential input of mass media especially the press, in its advertising capacity.

(Chapman, 2005); (Chen, Z. F. , \& Cheng, Y., 2019) As far back as 1880, mass media had shown very deep partnership involvement in human-related development(Napoli, 2008). The Prussians paved the way for public education in the eighteenth century school attendance was made compulsory in the Great Britain following the British's first education Act in 1880 (Napoli, 2008). As far back as 1789 the French had realized the relevant importance of the media to motivate political awareness and mobilize the public, the development which transformed education to a secular phenomenon in 1882 (Chapman, 2005). In America, education became a public consumer service as government and individuals embraced its emergence as an economic investment, even as the Japanese used the media as a tool to mobilize civilization and national consciousness (Chapman, 2005).

Many opposition governments have tapped into the power of mass media to criticize government decisions and policies. In Germany, the media was employed by the opposition party to attack government. The relationship between CED and mass media has been established. Graham Jackson cited in Ava Carmel (1996) reiterates that community development can be promoted by passing laws, developing appropriate media technology to encourage desirable social attitudes, and behavior changes using comprehensive integrated communication campaign.

Several other researchers have demonstrated the indisputable influence of media on behavioral changes in human being. Over time, the sociological capability of media hasgone beyond the primary cardinal functions of information, education and entertainment. The role of mass media has assumed creation of the environment for solving socio-cultural, socio-economic and socio-political issues that has provided fertile grounds for developmental programme. Some of these areas of concern have not only been founded on the premise of striking balance between different types and forms of communication, but also have always centered on the efficacious power of the media on social change.

\section{Media and Economic Development.}

Media can boost economic development by promoting good governance and empowering citizens, so that economies can function better. The Georgia Economic Developers Association (GEDA) defines economic development as a sustainable process of creating economic opportunity for all citizens; stimulating business investment; diversifying the public revenue base; and enhancing quality of life. Economic development, according to the US Department of Commerce, is fundamentally about enhancing the factors of productive capacity of a national economy.It is about economic growth, increase in competitiveness, sustainable development, reduction of poverty and inequality, increasing 
wages and benefits, and industrial policy. The key areas associated with media contribution to economic development are:

\section{RESEARCH METHODS}

\section{Research Design}

The study adopted descriptive research design of thesurvey type. Descriptive research method was more appropriate for this study as it allowed the researcher to conduct an indepth investigation to find out the mass media as a means of initiating community developmental programmes in Akoko North West Local Government Area ofOndo State, Nigeria.

\section{Population of the Study}

The population of this study comprised of all residents of Akoko North WestLocal Government Area of Ondo State, Nigeria.

\section{Sample of the Study}

The sample for the study was one hundred and twenty (120) respondents randomly selected from the study area.

\section{Instrument}

The instrument used for the research was structured questionnaire.

\section{Data Analysis}

The data collected were analyzed through the use of descriptive statistics of frequency counts and percentage.

\section{RESULTS AND DISCUSSION}

Research Question One: How mass media does contributes to community developmental programmes?

Table 1. Respondents response on how media contributes to developmentalprogrammes

\begin{tabular}{|c|c|c|c|c|c|c|c|c|}
\hline \multirow[b]{2}{*}{$\mathbf{S} / \mathbf{N}$} & \multirow[b]{2}{*}{ STATEMENT } & \multicolumn{6}{|c|}{ RESPONSES } & \multirow[b]{2}{*}{ TOTAI } \\
\hline & & $\mathbf{S A}$ & $\overline{\mathbf{A}}$ & $\mathbf{D}$ & SD & $\begin{array}{l}\text { ME } \\
\text { AN }\end{array}$ & $\begin{array}{l}\text { STD. } \\
\text { DEV }\end{array}$ & \\
\hline 1. & $\begin{array}{l}\text { Mass media is } \\
\text { important for the } \\
\text { general development } \\
\text { of our communities }\end{array}$ & $\begin{array}{l}70 \\
58.3 \%\end{array}$ & $\begin{array}{l}31 \\
25.8 \%\end{array}$ & $\begin{array}{l}9 \\
7.5 \%\end{array}$ & $\begin{array}{l}10 \\
8.3 \%\end{array}$ & 3.34 & 0.939 & $\begin{array}{l}120 \\
100.0\end{array}$ \\
\hline 2. & $\begin{array}{l}\text { Mass media is } \\
\text { important to the } \\
\text { general development } \\
\text { of our communities }\end{array}$ & $\begin{array}{l}36 \\
30.0 \%\end{array}$ & $\begin{array}{l}69 \\
57.5 \%\end{array}$ & $\begin{array}{l}9 \\
7.5 \%\end{array}$ & $\begin{array}{l}6 \\
5.0 \%\end{array}$ & 3.13 & 0.751 & $\begin{array}{l}120 \\
100.0\end{array}$ \\
\hline 3. & $\begin{array}{l}\text { Mass media will } \\
\text { attract government's } \\
\text { attention to our } \\
\text { communities for } \\
\text { developmental } \\
\text { programmes }\end{array}$ & $\begin{array}{l}58 \\
48.3 \%\end{array}$ & $\begin{array}{l}43 \\
35.8 \%\end{array}$ & $\begin{array}{l}58 \\
48.3 \%\end{array}$ & $\begin{array}{l}7 \\
5.8 \%\end{array}$ & 3.27 & 0.867 & $\begin{array}{l}120 \\
100.0\end{array}$ \\
\hline 4. & Mass media will help & 38 & 65 & 11 & 6 & 3.13 & 0.773 & 120 \\
\hline
\end{tabular}




\begin{tabular}{llllllll}
\hline & $31.7 \%$ & $54.2 \%$ & $9.2 \%$ & $5.0 \%$ & & & 100.0 \\
$\begin{array}{l}\text { to mobilize our } \\
\text { people for the } \\
\text { development of our } \\
\text { communities }\end{array}$ & & & & & & \\
\hline $5 . \quad \begin{array}{l}\text { Mass media will } \\
\text { serve as a veritable } \\
\text { tool for the } \\
\text { mobilization of the }\end{array}$ & $36.7 \%$ & $37.5 \%$ & $12.5 \%$ & $13.3 \%$ & & & 100.0 \\
$\begin{array}{l}\text { residents for } \\
\text { participation in } \\
\text { developmental } \\
\text { activities }\end{array}$ & & & & & & & \\
\hline $6 . \quad \begin{array}{l}\text { Mass media } \\
\text { contribute to } \\
\text { community } \\
\text { development by } \\
\text { highlight the plight } \\
\text { of the resident in the } \\
\text { study area }\end{array}$ & $33.3 \%$ & $44.2 \%$ & $12.5 \%$ & $10.0 \%$ & & & \\
\hline
\end{tabular}

Source: Researcher's survey, 2019

The Table above shows the result of research question one which stated that media contribute to community development programmes, from the result $58.3 \%$ of the respondent strongly agreed that mass media is important for the general development of our communities, $25.8 \%$ agreed while $7.5 \%$ disagreed and $8.3 \%$ strongly disagreed with the mean of 3.34 and standard deviation of $0.939,30.0 \%$ of the respondents strongly agreed that mass media is important to the general development of our communities, as $57.5 \%$ agreed while $7.5 \%$ and $5.0 \%$ disagreed and strongly disagreed respectively with the mean of 3.13 and standard deviation of $0.751,48.3 \%$ and $35.8 \%$ of the respondents also strongly agreed and agreed respectively that mass media will attract government's attention to our communities for developmental programmes as $48.3 \%$ and $5.8 \%$ disagreed and strongly disagreed respectively with the mean of 3.27 and standard deviation of 0.867 , $31.7 \%$ of the respondent also strongly agreed that mass media will help to mobilize our people for the development of our communities, $54.2 \%$ agreed while $9.2 \%$ disagreed as $5.0 \%$ strongly disagreed with 3.13 as the mean and 0.773 as the standard deviation. It is shown from item 5 that $36.7 \%$ and $37.5 \%$ strongly agreed and agreed respectively that mass media will serve as a veritable tool for the mobilization of the residents for participation in developmental activities while $12.5 \%$ and $13.3 \%$ disagreed and strongly disagreed respectively with the mean of 2.98 and standard of deviation of 1.016.

Finally, $33.3 \%$ of the respondent strongly agreed that Mass media contribute to community development by highlight the plight of the resident in the study area, $44.2 \%$ agreed while $12.5 \%$ disagreed and $10.0 \%$ strongly disagreed with the mean of 3.01 and standard deviation of 0.930

The result revealed that mass media helps in highlighting the problems of the community and also serve as the tool for mobilizing people of the community for the development of the community and mass media will also attract government attention to communities for developmental programme. Therefore, mass media is important for the general development of the community. 
Research Question Two: What are the factors which influence the role of mass media in developmental programmes in Akoko North West Local Government Area of Ondo State, Nigeria?

Table 2. Respondents view on the factors influencing the role of mass media in Akoko North West Local Government Area of Ondo State, Nigeria

\begin{tabular}{|c|c|c|c|c|c|c|c|c|}
\hline \multirow[b]{2}{*}{$\mathbf{S} / \mathbf{N}$} & \multirow[b]{2}{*}{ STATEMENT } & \multicolumn{6}{|c|}{ RESPONSES } & \multirow[b]{2}{*}{ TOTAL } \\
\hline & & SA & $\mathbf{A}$ & D & SD & $\begin{array}{l}\text { ME } \\
\text { AN }\end{array}$ & $\begin{array}{l}\text { STD. } \\
\text { DEV }\end{array}$ & \\
\hline 7. & $\begin{array}{l}\text { Over concentration } \\
\text { on government's } \\
\text { activities by the } \\
\text { media do not allow } \\
\text { them much time for } \\
\text { community } \\
\text { development issues }\end{array}$ & $\begin{array}{l}56 \\
46.7 \%\end{array}$ & $\begin{array}{l}15 \\
12.5 \%\end{array}$ & $\begin{array}{l}32 \\
26.7 \%\end{array}$ & $\begin{array}{l}17 \\
14.2 \%\end{array}$ & 2.92 & 1.142 & $\begin{array}{l}120 \\
100.0\end{array}$ \\
\hline 8. & $\begin{array}{l}\text { The mass media in } \\
\text { the area concentrate } \\
\text { too much on } \\
\text { politics to the } \\
\text { detriment of } \\
\text { developmental } \\
\text { issues concerning } \\
\text { the community }\end{array}$ & $\begin{array}{l}21 \\
17.5 \%\end{array}$ & $\begin{array}{l}50 \\
41.7 \%\end{array}$ & $\begin{array}{l}35 \\
29.2 \%\end{array}$ & $\begin{array}{l}14 \\
11.7 \%\end{array}$ & 2.65 & 0.904 & $\begin{array}{l}120 \\
100.0\end{array}$ \\
\hline 9. & $\begin{array}{l}\text { The absence of } \\
\text { community media } \\
\text { house is a major } \\
\text { constraint to the } \\
\text { development of the } \\
\text { rural areas }\end{array}$ & $\begin{array}{l}37 \\
30.8 \%\end{array}$ & $\begin{array}{l}40 \\
33.3 \%\end{array}$ & $\begin{array}{l}35 \\
29.2 \%\end{array}$ & $\begin{array}{l}8 \\
6.7 \%\end{array}$ & 2.88 & 0.927 & $\begin{array}{l}120 \\
100.0\end{array}$ \\
\hline 10. & $\begin{array}{l}\text { Inability to } \\
\text { broadcast in } \\
\text { indigenous } \\
\text { languages, is strong } \\
\text { factor affecting the } \\
\text { media activities in } \\
\text { the study area }\end{array}$ & $\begin{array}{l}42 \\
35.0 \%\end{array}$ & $\begin{array}{l}49 \\
40.8 \%\end{array}$ & $\begin{array}{l}18 \\
15.0 \%\end{array}$ & $\begin{array}{l}11 \\
9.2 \%\end{array}$ & 3.02 & 0.935 & $\begin{array}{l}120 \\
100.0\end{array}$ \\
\hline 11. & $\begin{array}{l}\text { Government policy } \\
\text { have great } \\
\text { influence on the } \\
\text { role of media house }\end{array}$ & $\begin{array}{l}34 \\
28.3 \%\end{array}$ & $\begin{array}{l}45 \\
37.5 \%\end{array}$ & $\begin{array}{l}13 \\
10.8 \%\end{array}$ & $\begin{array}{l}28 \\
23.3 \%\end{array}$ & 2.71 & 1.118 & $\begin{array}{l}120 \\
100.0\end{array}$ \\
\hline
\end{tabular}

Source: Researcher's survey, 2019

The Table above shows the result of research question two which stated that factors influencing the role of mass media in Akoko North-West development, from the result $46.7 \%$ of the respondents strongly agreed that over concentration on government's activities by the media do not allow them much time for community development issues, as $12.5 \%$ agreed while $26.7 \%$ and $14.2 \%$ disagreed and strongly disagreed respectively with the mean of 2.92 and standard deviation of $1.142,17.5 \%$ and $41.7 \%$ of the respondents also strongly agreed and agreed respectively that the mass media in the area concentrate too much on politics to the detriment of developmental issues concerning the community as $29.2 \%$ and $11.7 \%$ disagreed and strongly disagreed respectively with the 
mean of 2.65 and standard deviation of $0.904,30.8 \%$ of the respondents also strongly agreed that the absence of community media house is a major constraint to the development of the rural areas, $33.3 \%$ agreed while $29.2 \%$ disagreed as $6.7 \%$ strongly disagreed with 2.88 as the mean and 0.927 as the standard deviation, $35.0 \%$ and $40.8 \%$ strongly agreed and agreed respectively that Inability to broadcast in indigenous languages, is strong factor affecting the media activities in the study area while $15.0 \%$ and $9.2 \%$ disagreed and strongly disagreed respectively with the mean of 3.02 and standard of deviation of 0.935 . Finally item 11 reveals that $28.3 \%$ of the respondent strongly agreed that government policy have great influence on the role of media house, $37.5 \%$ agreed while $10.8 \%$ disagreed and $23.3 \%$ strongly disagreed with the mean of 2.71 and standard deviation of 1.118

It is clear from the result that government policy has great influence on the role of media house; therefore, the mass media concentrate too much on politics to the detriment of developmental issues concerning the community. The unavailability of media house in the community and the inability of mass media to broadcast in indigenous languages is an important factor affecting the media in the study area.

Research Question Three: Ways media initiate and enhance development in the society

Table 3. Respondents response on ways media initiate and enhance development in the society

\begin{tabular}{|c|c|c|c|c|c|c|c|c|}
\hline \multirow[b]{2}{*}{$\mathbf{S} / \mathbf{N}$} & \multirow[b]{2}{*}{ STATEMENT } & \multicolumn{6}{|c|}{ RESPONSES } & \multirow[b]{2}{*}{ TOTAL } \\
\hline & & SA & A & $\mathbf{D}$ & SD & $\begin{array}{l}\text { ME } \\
\text { AN }\end{array}$ & $\begin{array}{l}\text { STD. } \\
\text { DEV }\end{array}$ & \\
\hline 12. & $\begin{array}{l}\text { Media can help } \\
\text { initiate and enhance } \\
\text { develepoment in } \\
\text { the society through } \\
\text { educative } \\
\text { programmes }\end{array}$ & $\begin{array}{l}56 \\
46.7 \%\end{array}$ & $\begin{array}{l}33 \\
27.5 \%\end{array}$ & $\begin{array}{l}17 \\
14.2 \%\end{array}$ & $\begin{array}{l}14 \\
11.7 \%\end{array}$ & 3.09 & 1.037 & $\begin{array}{l}120 \\
100.0\end{array}$ \\
\hline 13. & $\begin{array}{l}\text { Media can help } \\
\text { initiate and enhance } \\
\text { development in the } \\
\text { society by } \\
\text { encouraging people } \\
\text { to participate in } \\
\text { developmental } \\
\text { activities }\end{array}$ & $\begin{array}{l}35 \\
29.2 \%\end{array}$ & $\begin{array}{l}61 \\
50.8 \%\end{array}$ & $\begin{array}{l}12 \\
10.0 \%\end{array}$ & $\begin{array}{l}12 \\
10.0 \%\end{array}$ & 2.99 & 0.893 & $\begin{array}{l}120 \\
100.0\end{array}$ \\
\hline 14. & $\begin{array}{l}\text { Government as } \\
\text { development } \\
\text { partner can use } \\
\text { mass media to } \\
\text { reach out to the } \\
\text { residents for } \\
\text { participation in } \\
\text { developmental } \\
\text { activities }\end{array}$ & $\begin{array}{l}41 \\
34.2 \%\end{array}$ & $\begin{array}{l}39 \\
32.5 \%\end{array}$ & $\begin{array}{l}30 \\
25.0 \%\end{array}$ & $\begin{array}{l}10 \\
8.3 \%\end{array}$ & 2.93 & 0.963 & $\begin{array}{l}120 \\
100.0\end{array}$ \\
\hline 15. & $\begin{array}{l}\text { Mass media can } \\
\text { assist in the } \\
\text { actualization in the } \\
\text { developmental need }\end{array}$ & $\begin{array}{l}38 \\
31.7 \%\end{array}$ & $\begin{array}{l}54 \\
45.0 \%\end{array}$ & $\begin{array}{l}14 \\
11.7 \%\end{array}$ & $\begin{array}{l}14 \\
11.7 \%\end{array}$ & 2.97 & 0.952 & $\begin{array}{l}120 \\
100.0\end{array}$ \\
\hline
\end{tabular}




\begin{tabular}{|c|c|c|c|c|c|c|c|c|}
\hline & $\begin{array}{l}\text { of the people by } \\
\text { concentrating more } \\
\text { on grassroots } \\
\text { programmes }\end{array}$ & & & & & & & \\
\hline 16. & $\begin{array}{l}\text { Media can help } \\
\text { initiate and enhance } \\
\text { development in the } \\
\text { society by } \\
\text { partnering with } \\
\text { government for } \\
\text { developmental } \\
\text { projects }\end{array}$ & $\begin{array}{l}26 \\
21.7 \%\end{array}$ & $\begin{array}{l}65 \\
54.2 \%\end{array}$ & $\begin{array}{l}10 \\
8.3 \%\end{array}$ & $\begin{array}{l}19 \\
15.8 \%\end{array}$ & 2.82 & 0.953 & $\begin{array}{l}120 \\
100.0\end{array}$ \\
\hline
\end{tabular}

Source: Researcher's survey, 2019

The Table above shows the result of research question three which stated that ways media initiate and enhance development in the society, from the result that $46.7 \%$ of the respondents strongly agreed that media can help initiate and enhance development in the society through educative programmes, as $27.5 \%$ agreed while $14.2 \%$ and $11.7 \%$ disagreed and strongly disagreed respectively with the mean of 3.09 and standard deviation of 1.037, $29.2 \%$ and $50.8 \%$ of the respondents also strongly agreed and agreed respectively that media can help initiate and enhance development in the society by encouraging people to participate in developmental activities as $10.0 \%$ disagreed and strongly disagreed respectively with the mean of 2.99 and standard deviation of $0.893,34.2 \%$ of the respondent also strongly agreed that government as development partner can use mass media to reach out to the residents for participation in developmental activities, $32.5 \%$ agreed while $25.0 \%$ disagreed as $8.3 \%$ strongly disagreed with 2.93 as the mean and 0.693 as the standard deviation, $31.7 \%$ and $45.0 \%$ strongly agreed and agreed respectively that mass media can assist in the actualization in the developmental need of the people by concentrating more on grassroots programmes while $11.7 \%$ disagreed and strongly disagreed respectively with the mean of 2.97 and standard deviation of 0.952 . Finally, it is shown from item 16 that $21.7 \%$ of the respondent strongly agreed that media can help initiate and enhance development in the society by partnering with government for developmental projects, $54.2 \%$ agreed while $8.3 \%$ disagreed and $15.8 \%$ strongly disagreed with the mean of 2.82 and standard deviation of 0.953

The result revealed that mass media can help in initiating and enhancing development in the society by concentrating more on grassroots and educative programmes to encourage people to participate in developmental activities and most especially, mass media can partner with government to help actualize development in the community.

Research Question Four: Communication helps to promote developmental projects that brings about positive changes

Table 4. Respondents response on how communication helps to promote developmental projects that brings about positive changes

\begin{tabular}{|c|c|c|c|c|c|c|c|c|}
\hline \multirow[b]{2}{*}{$\mathbf{S} / \mathbf{N}$} & \multirow[b]{2}{*}{ STATEMENT } & \multicolumn{6}{|c|}{ RESPONSES } & \multirow[b]{2}{*}{ TOTAL } \\
\hline & & SA & $\mathbf{A}$ & D & SD & $\begin{array}{l}\text { ME } \\
\text { AN }\end{array}$ & $\begin{array}{l}\text { STD. } \\
\text { DEV }\end{array}$ & \\
\hline 17. & $\begin{array}{l}\text { Media can assist in } \\
\text { the actualization of } \\
\text { the developmental } \\
\text { needs of the people }\end{array}$ & $\begin{array}{l}52 \\
43.3 \%\end{array}$ & $\begin{array}{l}47 \\
39.2 \%\end{array}$ & $\begin{array}{l}14 \\
11.7 \%\end{array}$ & $\begin{array}{l}7 \\
5.8 \%\end{array}$ & 3.20 & 0.866 & $\begin{array}{l}120 \\
100.0\end{array}$ \\
\hline
\end{tabular}




\begin{tabular}{|c|c|c|c|c|c|c|c|c|}
\hline & $\begin{array}{l}\text { by concentrating } \\
\text { more on grassroot } \\
\text { programmes }\end{array}$ & & & & & & & \\
\hline 18. & $\begin{array}{l}\text { Mass media can } \\
\text { assist in the } \\
\text { actualization of the } \\
\text { developmental needs } \\
\text { of the rural people by } \\
\text { presenting those } \\
\text { needs to the } \\
\text { government }\end{array}$ & $\begin{array}{l}29 \\
24.2 \%\end{array}$ & $\begin{array}{l}85 \\
70.8 \%\end{array}$ & $\begin{array}{l}6 \\
5.0 \%\end{array}$ & - & 3.19 & 0.507 & $\begin{array}{l}120 \\
100.0\end{array}$ \\
\hline 19. & $\begin{array}{l}\text { Mass media can } \\
\text { promote } \\
\text { developmental } \\
\text { project by mobilizing } \\
\text { members of } \\
\text { community to } \\
\text { participate }\end{array}$ & $\begin{array}{l}53 \\
44.2 \%\end{array}$ & $\begin{array}{l}47 \\
39.2 \%\end{array}$ & $\begin{array}{l}13 \\
10.8 \%\end{array}$ & $\begin{array}{l}7 \\
5.8 \%\end{array}$ & 3.22 & 0.862 & $\begin{array}{l}120 \\
100.0\end{array}$ \\
\hline 20. & $\begin{array}{l}\text { Media can assist in } \\
\text { the actualization of } \\
\text { the developmental } \\
\text { needs of the people } \\
\text { by focusing on the } \\
\text { community burring } \\
\text { issues }\end{array}$ & $\begin{array}{l}21 \\
17.5 \%\end{array}$ & $\begin{array}{l}688 \\
56.7 \%\end{array}$ & $\begin{array}{l}22 \\
18.3 \%\end{array}$ & $\begin{array}{l}9 \\
7.5 \%\end{array}$ & 2.84 & 0.799 & $\begin{array}{l}120 \\
100.0\end{array}$ \\
\hline 21 & $\begin{array}{l}\text { Mass media can help } \\
\text { to improve dialogue } \\
\text { and create space for } \\
\text { listening and } \\
\text { implementing } \\
\text { development project }\end{array}$ & $\begin{array}{l}39 \\
32.5 \%\end{array}$ & $\begin{array}{l}59 \\
49.2 \%\end{array}$ & $\begin{array}{l}11 \\
9.2 \%\end{array}$ & $\begin{array}{l}11 \\
9.2 \%\end{array}$ & 3.05 & 0.887 & $\begin{array}{l}120 \\
100.0\end{array}$ \\
\hline
\end{tabular}

Source: Researcher's survey, 2019

The Table above shows the result of research question three which stated that communication help to promote development projects that bring positive changes, from the result, $43.3 \%$ of the respondents strongly agreed that media can assist in the actualization of the developmental needs of the people by concentrating more on grassroots programmes, as $39.2 \%$ agreed while $11.7 \%$ and $5.8 \%$ disagreed and strongly disagreed respectively with the mean of 3.20 and standard deviation of $0.866,24.2 \%$ and $70.8 \%$ of the respondents also strongly agreed and agreed respectively that mass media can assist in the actualization of the developmental needs of the rural people by presenting those needs to the government as $5.0 \%$ disagreed and none of the respondent strongly disagreed respectively with the mean of 3.19 and standard deviation of $0.507,44.2 \%$ of the respondent also strongly agreed that mass media can promote developmental project by mobilizing members of community to participate, $39.2 \%$ agreed while $10.8 \%$ disagreed as $5.8 \%$ strongly disagreed with 3.22 as the mean and 0.862 as the standard deviation. It is shown from item 20 that $17.5 \%$ and $56.7 \%$ strongly agreed and agreed respectively that media can assist in the actualization of the developmental needs of the people by focusing on the community burring issues while $18.3 \%$ and $7.5 \%$ disagreed and strongly disagreed respectively with the mean of 2.84 and standard of deviation of 0.799 . Finally, item 21 reveals that $32.5 \%$ of the respondent strongly agreed as 49.2 agreed that Mass media can 
help to improve dialogue and create space for listening and implementing development project while $9.2 \%$ disagreed and strongly disagreed respectively.

The result revealed that mass media can help to improve dialogue and create space for listening and implementation development project that enables them to know the issues affecting the community. Mass media can also assist the actualization of community development by presenting the community needs to the government and mobilize members of the community to participate in developmental projects.

\section{Discussion of Findings}

This study sought to examine mass media as a means of initiating community developmental programmes in Akoko North West Local Government Area, Ondo State, Nigeria. The distinctive operating conditions such as nature of audience, communication experience and the communicator that connotes or which is one of the key features of mass media made it one of the tools used in initiating and actualizing social factors in which community development is vital among these social activities.

From the research question one which stated that how media contributes to developmental programmes. Highlighting the problems of the community and also mobilizing people of the community for the development of the community tends to be easier for mass media because of the features that defines mass media itself has covered their ability to get information and share it and also make sure the information shared gets to the right people, which makes it the best platform for mobilizing people of the community for participation and mass media will also attract government attention to communities for developmental programme. Therefore, mass media is important for the general development of the community.

From research question two which state the factors influencing the role of mass media in Akoko North-West development. The respondents agreed that government policy has great influence on the role of media house; therefore, the mass media concentrate too much on politics to the detriment of developmental issues concerning the community. The unavailability of media house in the community and the inability of mass media to broadcast in indigenous languages is an important factor affecting the media in the study area.

From research question three whish says the ways media initiate and enhance development in the society, it is revealed that mass media can initiate development in the community by concentrating more on the issues affecting the community and also mobilize members of the community to participate in the developmental projects going on in the society and mass media can also be an intermediary between the community and the government by partnering with the government to actualize development in the society.

Research question four which stated that communication help to promote development projects that bring positive changes. Mass media has all it takes to communicate with the members of the community in which can be used to initiate and enhance the development of the community, mass media can help to improve dialogue and create space for listening and implementation of development programmes that enables them to know the issues affecting the community. Mass media can also assist the actualization of community development by presenting the community needs to the government and mobilize members of the community to participate in developmental projects with their power of communication. 


\section{CONCLUSION}

Based on the findings, the study concluded that mass media can also assist the actualization of community development by presenting the community needs to the government and mobilize members of the community to participate in developmental projects with their power of communication. Media initiate and enhance development in the society. Mobilize members of the community to participate in the developmental projects going on in the society as serve as an intermediary between the community and the government by partnering with the government to actualize development in the society.

\section{Recomendations}

Based on the findings of the study, it is therefore recommended that:

- communities can sustain their projects if they are highly involved in the projects. It is highly recommended that the collaboration and empowerment form of participation is encouraged by development agencies. With these forms of participation communities can come out with what their needs are and because they will initiate it themselves they will be accountable and take responsibility for its sustenance. It is again recommended that communities and for that matter households should cultivate the habit of embarking on self-initiated projects and also set up committee to manage initiated projects. They should be their own agent of change

- project implementers should adopt the social mobilization element of development communication by reaching out to opinion leaders who have the tendency to reach out to a large number of community members to inform them about the projects. This will help all members to become aware of the projects as these leaders have greater influence on the people

- sustainability strategies must include communication strategies which should indicate how the various stakeholders will be involved in promoting a project's sustenance and also how the strategies will be communicated to the communities. These strategies should also be made available for all stakeholders to be aware of the roles they will play as far as sustainability of projects are concern.

- the Federal Government of Nigeria (FGN) needs to grant licenses for the establishment and operation of true community radio stations. This will enable rural people especially the common mass to have a sense of belonging as well as helping them to propagate developmental messages among themselves.

\section{REFERENCES}

Adedokun, M. O., Adeyemo, C .W. and Olorunsola, E. O. (2010). The Impact of Communication on Community Development. Institute of Education, University of Ado-Ekiti. Ado-Ekiti, Nigeria.

Akinfeyemi, R. (1993). Mass Media and the Promotion of Rural Development in Nigeria: The last ten years. In Akeredolu, A. (Ed). Mass Media and Rural Development in Nigeria. Ibadan: Spectrum books Ltd.

Akianmu S. E and Akinsanya S. (ed.) (2004). Building community radio in Nigeria: issues and challenges. Imeso and PIWA.

Akingbulu A. E. (2011). Empowering national development in Nigeria through appropriate national communication policy. Singaporean Journal of Business Economics, and Management Studies, 1(4).

Anakwe, A. , Majee, W. , \& Keller, K.J.M. (2018). Family structure diversity: Views from rural community leaders and implications for youth engagement . Manuscript submitted for publication (Manuscript submitted for publication). [Google Scholar] 
Balogun, M. O. (1994). Communication, a key to human development. Food and Agricultural Organisation. New York.

Bandura, A. (2002). Environmental sustainability by socio cognitive declaration of population growth. In W. P. Peter Schmuck, Sociology of sustainable development (p. 208). Massachussetts: Kluwer Academic Publishers.

Berthon, P. R. , \& Pitt, L. F. (2018). Brands, truthiness and post-fact: Managing brands in a post-rational world. Journal of Macromarketing, 28(2), 218-227. https://doi.org/10.1177/0276146718755869 [Crossref], [Google Scholar]

Chambers, B. S. (1991). "Development Communication." The International Encyclopedia of Communication: Donsbach, Wolfgang (ed). Blackwell Publishing.

Chapman, J. (2005). Media Industrialization and Imperialism. In J. Chapman, Comparative Media History (pp. 55-80). Malden: Polity Press.

Chen, Z. F. , \& Cheng, Y. (2019). Consumer response to fake news about brands on social media: The effects of self-efficacy, media trust, and persuasion knowledge on company trust. Journal of Product \& Brand Management, 29(2), 188-198. https://doi.org/10.1108/JPBM-12-2018-2145 [Crossref], [Google Scholar]

Cheng, Y. , Jin, Y. , Hung-Baesecke, C.-J. F. , \& Chen, Y. R. (2019). Mobile corporate social responsibility (mCSR): Examining publics' responses to CSR-based initiatives in natural disasters. International Journal of Strategic Communication, 13(1), 76-93. https://doi.org/10.1080/1553118X.2018.1524382 [Taylor \& Francis Online], [Google Scholar]

Locksley, N. O. (2009). Media and global change; rethinking Communication for Development.Nordicom and CLACSO.

Servaes, J. (2000). 'Advocacy Strategies for Development Communication', in J. Servaes (ed.) Walking on the Other Side of the Information Highway. Communication, Culture and Development in the 21st Century. Penang: Southbound.

Servaes, J. (2008). Communication for development, one world, multiple cultures,. Cresskill NJ: Hampton Press. 